\title{
Enhancing the removal of hazardous pollutants from coke making wastewater by dosing activated carbon to a pilot-scale activated sludge process
}

\section{Application of activated carbon for coke making wastewater treatment.}

\author{
Authors: Eleanor Raper ${ }^{\mathrm{a}}$, Ana Soares ${ }^{\mathrm{a},}$, Jie Chen ${ }^{\mathrm{b}}$, Adam Sutcliffe ${ }^{\mathrm{b}}$, Eric Aries ${ }^{\mathrm{b} * *}$, David \\ Anderson ${ }^{\mathrm{b}}$, Tom Stephenson ${ }^{\mathrm{a}}$.
}

\begin{abstract}
Affiliation:
${ }^{a}$ Cranfield University Water Sciences Institute, Cranfield University, Cranfield, MK43 0AL, UK. e.raper@cranfield.ac.uk (01709 820166),*a.soares@cranfield.ac.uk (Corresponding Author- 01234 758121),T.Stephenson@cranfield.ac.uk (01234754054).

${ }^{\mathrm{b}}$ Tata Steel, Group Environment, Swinden Technology Centre, Rotherham, S60 3AR, UK. jie.chen@tatasteel.com (01709 820166), a.sutcliffe@tatasteel.com (01709 820166), david.anderson@tatasteel.com(01709 820166).

** please note this author has changed position contact should therefore be made through an alternative author as contact information is restricted.
\end{abstract}

\section{$\underline{\text { ABSTRACT }}$ \\ BACKGROUND}

Powdered activated carbon (PAC) was investigated for its ability to remove 6 polycyclic aromatic hydrocarbons ( $26 \mathrm{PAHs}) \quad$ (fluoranthene, benzo[b+J]fluoranthene, benzo[k]fluoranthene, benzo[a]pyrene, indeno[1,2,3-cd]pyrene, benzo[g,h,i]perylene), trace metals and colour from coke making wastewater when dosed to a pilot-plant activated sludge process (ASP). The ASP had a volume of $0.68 \mathrm{~m}^{3}$ and was operated to simulate the full-scale ASP treating coke wastewater from a steel works. Operational conditions included a flow rate of $0.78 \mathrm{~m}^{3} /$ day, a hydraulic retention time of 21 hours, a sludge retention time of 38 days and a temperature of $27^{\circ} \mathrm{C}$. The ASP was operated for a control period before PAC was dosed directly into the aeration cell at a dose of $400 \mathrm{mg} / \mathrm{L}$.

\section{RESULTS}

This article has been accepted for publication and undergone full peer review but has not been through the copyediting, typesetting, pagination and proofreading process, which may lead to differences between this version and the Version of Record. Please cite this article as doi: $10.1002 /$ jctb.5231

This article is protected by copyright. All rights reserved. 
Powdered activated carbon addition resulted in a $20 \%$ increase in removal efficiency of the ¿6PAHs. Removal efficiency of trace metals was variable, but increased for nickel, chromium and cadmium by $22.6 \%, 20.5 \%$ and $12.4 \%$, respectively. Improvement in colour removal efficiency was marginal at $5 \%$.

\section{CONCLUSION}

PAC addition allowed the improvement of treatment efficiencies in the ASP process at relatively low capital and operational costs, which may assist in reaching tighter effluent emission limits set for the industry.

\section{KEYWORDS}

Activated carbon Polycyclic aromatic hydrocarbons Trace metals Activated sludge process Coke wastewater

\section{INTRODUCTION}

Coke making wastewaters originate from the quenching of hot coke masses and washing of ammonia stills as well as the cooling and washing of coke oven gases ${ }^{1}$. Coke making wastewater contains numerous compounds capable of causing toxic effects in the environment including ammonia $\left(\mathrm{NH}_{4}{ }^{+}\right)$, thiocyanate $\left(\mathrm{SCN}^{-}\right)$, cyanide $\left(\mathrm{CN}^{-}\right)$, phenols, polycyclic aromatic hydrocarbons $(\mathrm{PAHs})$ and trace metals ${ }^{2-8}$. Characteristics of coke making wastewater vary between production plants in response to both the composition of the coals used and differences in plant operation ${ }^{3}$. Ammonia concentrations have been reported from as low as $123 \mathrm{mg} / \mathrm{L}^{9}$ up to $4500 \mathrm{mg} / \mathrm{L}^{10}$. Thiocyanate was reported by Gould 10 in the range of 130 to $860 \mathrm{mg} / \mathrm{L}$ with values of ca. $200 \mathrm{mg} / \mathrm{L}$ being reported at other

This article is protected by copyright. All rights reserved. 
treatment plants ${ }^{9,11}$. Phenol concentrations also vary between plants from as low as $60 \mathrm{mg} / \mathrm{L}$ ${ }^{11}$ to $1900 \mathrm{mg} / \mathrm{L}^{10}$ with average values of ca. $250 \mathrm{mg} / \mathrm{L}^{10,12}$. Typically chemical oxygen demand (COD) averages at $2300 \mathrm{mg} / \mathrm{L}^{10-12}$ whilst biological oxygen demand (BOD) shows large degrees of variation from $683 \mathrm{mg} / \mathrm{L}^{12}$ to $2800 \mathrm{mg} / \mathrm{L}^{10}$.

As a result of increasing concern over pollutant emissions to the aquatic environment emission limits for industrial wastewater have become increasingly stringent. New emission limits were introduced in 2016 for coke making wastewaters under the Industrial Emissions Directive (IED) ${ }^{13}$. Six PAHs (इ6PAHs: fluoranthene, benzo[b]fluoranthene, benzo[k]fluoranthene, benzo[a]pyrene, indeno[1,2,3-cd]pyrene and benzo[g,h,i]perylene) and some metals have been identified in the best available technology (BAT) reference document for the production of iron and steel ${ }^{13}$ but there is little information available on their concentrations in coke making wastewater. Zhang et al. ${ }^{14}$ reported $\Sigma 18$ PAHs of $5470 \pm 907$ $\mu \mathrm{g} / \mathrm{L}$ and $4.7 \pm 0.4 \mu \mathrm{g} / \mathrm{L}$ in untreated and treated wastewater, respectively. Recently $\Sigma 6 \mathrm{PAHs}$ were reported for treated effluent from a UK steel making wastewater with average concentrations of $36.3 \mu \mathrm{g} / \mathrm{L}$ and a range of $8.5-99.4 \mu \mathrm{g} / \mathrm{L}^{8}$. Burmistrz and Burmistrz ${ }^{15}$ reported EPA $\Sigma 16$ PAHs in untreated coke wastewater varying between $255-312 \mu \mathrm{g} / \mathrm{L}$ and $0.94-4.46 \mu \mathrm{g} / \mathrm{L}$ in treated effluent. Chen et al. ${ }^{8}$ also reported trace metal emission factors for cadmium $(\mathrm{Cd})$, lead $(\mathrm{Pb})$, nickel $(\mathrm{Ni})$, chromium $(\mathrm{Cr})$, iron $(\mathrm{Fe})$, copper $(\mathrm{Cu})$, zinc $(\mathrm{Zn})$ and arsenic (As) of 0.04, 4.7, 6.0, 11.7, 1003, 1.1, 410 and $4.6 \mathrm{mg} /$ tonne of coke, respectively.

A number of trace metals and PAHs frequently occurring in coke making effluents have been listed as priority substances ${ }^{16}$ (Table I) under the Water Framework Directive (WFD) ${ }^{17}$. The new achievable emission limits introduced for coke making wastewaters based on emissions

This article is protected by copyright. All rights reserved. 
associated with the BAT ${ }^{13}$ consist of $<220 \mathrm{mg} / \mathrm{L} \mathrm{COD,}<20 \mathrm{mg} / \mathrm{L} \mathrm{BOD}{ }_{5},<4 \mathrm{mg} / \mathrm{L} \mathrm{SCN}^{-}$, $<0.1 \mathrm{mg} / \mathrm{L}$ easily released cyanide ion $\left(\mathrm{CN}^{-}\right),<50 \mu \mathrm{g} / \mathrm{L} \Sigma 6 \mathrm{PAHs}$ and $<15-50 \mathrm{mg} / \mathrm{L}$ for the sum of ammonia-nitrogen, nitrate-nitrogen and nitrite-nitrogen. In particular, the high variability of PAH concentrations in coke making effluent reported by Chen et al. ${ }^{8}$ means consistently achieving the emission limit may be problematic and consequently there is a need to improve pollutant removal efficiencies.

\section{Table I: Priority Hazardous Substances (PHS), Priority Substances (PS) and Specific Pollutants} (SP) associated with coke wastewaters.

The treatment of coke making wastewater typically takes place through biological treatment using activated sludge processes (ASP), although, many treatment plants also use initial pretreatment methods e.g. steam stripping and chemical coagulation ${ }^{6,18}$. Different treatment plants can also use different combinations of anoxic, anaerobic and aerobic treatment cells in order to reduce target pollutants.

The use of activated carbon (AC) has received considerable attention for a number of decades for the removal of pollutants found in both industrial ${ }^{19-26}$ and domestic wastewaters ${ }^{27-31}$ and may allow improved treatment efficiencies of coke making wastewater. Activated carbon can be applied as a pre-treatment method, dosed directly into the treatment process or applied as a post-treatment method ${ }^{32,33}$. It can also be in either a granular (GAC) or powdered (PAC) form. Due to its larger pore size GAC is more suitable for heavy molecular weight pollutants 34. When added into the ASP, it acts as an absorbent whilst also providing a surface for microorganisms to grow in a biofilm ${ }^{19,35}$. This allows pollutants to be absorbed and then

This article is protected by copyright. All rights reserved. 
diffused out gradually, allowing increased contact times between the microorganisms and pollutant, which enhances the removal of less easily degradable compounds which may require a higher residence time ${ }^{35}$.

Activated carbon has been successfully applied to PAHs and trace metal removal in a variety of industrial as well as domestic wastewaters using a range of AC types and operational configurations ${ }^{19-21,36-38}$. Removals of $96.9-99.7 \%$ of $\Sigma 36 \mathrm{PAHs}$ have been demonstrated in a batch mode pilot-scale biologically activated carbon system treating wastewaters containing petroleum products ${ }^{39}$. Furthermore, the benefit of addition of AC to coke making wastewaters has been demonstrated in a laboratory-scale continuous flow reactor. A dose rate of $300 \mathrm{mg} / \mathrm{L}$ and a hydraulic retention time (HRT) of $20 \mathrm{~h}$ resulted in a $26 \%$ increase in COD removal and more stable cyanide removal ${ }^{26}$. More recently a batch study using activated coke (carbonaceous material activated by steam and similar to $\mathrm{AC}$ but with a lower surface area) demonstrated improved removals of COD (91.6\%) and colour $(90 \%)$ at a dose rate of $200 \mathrm{~g} / \mathrm{L}^{40}$.

The majority of research focussing on $\mathrm{PAH}$ and trace metal removal with AC has been completed in batch systems. Goel et al. ${ }^{22}$ identified the limitations of applying those results to real treatment applications, explaining that in batch tests adsorption continues until an equilibrium is established but in a continuous treatment system this equilibrium is never achieved, resulting is significantly different efficiencies. Therefore, the objective of this study was to address the current gap in knowledge on the ability of AC to improve removal efficiencies of PAHs and trace metals from coke making wastewater in a continuous process at a significant scale $\left(0.68 \mathrm{~m}^{3}\right)$ pilot-plant. Results from this study can also offer insight on 
the treatability of other types of wastewaters that contain PAHs and or trace metals through an ASP with AC addition.

\section{EXPERIMENTAL}

Wastewater and activated sludge seed

Coke making wastewater and return activated sludge (for seeding the pilot-plant) were sourced from a UK, full-scale, industrial wastewater treatment plant (WWTP) that processed coke making wastewater. The full-scale WWTP included an inlet reservoir and an activated sludge process with 4 aeration tanks, followed by 2 clarifiers. Each aeration tank had a volume of $570 \mathrm{~m}^{3}$ and received wastewater at a flow rate of $680 \mathrm{~m}^{3} /$ day allowing for a HRT of 21 hours and a sludge retention time (SRT) of 38 days. Return activated sludge was recirculated from the clarifier to the aeration cell.

\section{$\underline{\text { Pilot-plant }}$}

In order to investigate the ability of PAC to treat coke making wastewater, an ASP pilot-plant was established following the configuration shown in Figure I. The pilot-plant followed the same configuration as the full-scale treatment plant running at an equivalent HRT and SRT of 21 hours and 38 days, respectively. The wastewater entered the aerobic cell at $0.78 \mathrm{~m}^{3} /$ day with an overflow into the clarifier. The settled sludge was recirculated at a flow rate of 1.6 $\mathrm{m}^{3} /$ day and waste sludge removed manually at a rate of $6 \mathrm{~L} /$ day. The temperature and dissolved oxygen was maintained at ca. $27^{\circ} \mathrm{C}$ and $2-4 \mathrm{mg} / \mathrm{L}$ respectively, the same conditions as the full-scale plant. The $\mathrm{pH}$ within the system averaged at 6.8 .

Figure I: Schematic representation of the activated sludge pilot-plant with PAC addition.

This article is protected by copyright. All rights reserved. 
The pilot-plant was operated for a control period, equivalent to 14 times the HRT, with samples collected 3 times per week for $\mathrm{PAH}$, trace metal, suspended solids and colour analysis. After the control period the pilot-plant was dosed with $400 \mathrm{mg} / \mathrm{L}$ of PAC directly into the aeration cell in batch mode 3 times per week. The PAC used was, a commercial product, produced from lignite and characterised by a grain size $\left(\mathrm{D}_{50}\right)$ of $24 \mu \mathrm{m}$, a bulk density of $0.44 \mathrm{~g} / \mathrm{cm}^{3}$, a specific surface area of $300 \pm 30 \mathrm{~m}^{2} / \mathrm{g}$ and a $0.5 \%$ moisture content. The PAC dose rate was based on a previous application by Chao et al. ${ }^{26}$ of $300 \mathrm{mg} / \mathrm{L}$, being increased to reflect the slightly higher average total phenol and thiocyanate levels in the studied coke making wastewater (Table II). Samples were taken for PAH, trace metal, suspended solids and colour analysis 3 times per week. Removal efficiencies of total phenol and $\mathrm{SCN}^{-}$were monitored throughout to ensure no negative impacts occurred due to PAC addition as the degradation of these compounds is an essential requirement for the successful treatment of coke making wastewater.

\begin{abstract}
Analysis
Total phenol

Total phenol analyses were completed by adding Folin Ciocalteu reagent and sodium carbonate $(20 \% \mathrm{w} / \mathrm{v})$ to filtered samples $(1.25 \mu \mathrm{m}$ filter $)$ and quantified by measurement in a spectrophotometer at wavelength of $760 \mathrm{~nm}(20 \mathrm{~mm}$ cell $)\left(\right.$ Cecil CE 1011) ${ }^{41}$.
\end{abstract}

\title{
Thiocyanate
}

Samples were filtered $(1.25 \mu \mathrm{m}$ filter $)$ and the $\mathrm{SCN}^{-}$concentration measured using a Galley photometric system (Thermo Scientific, United States) that was calibrated using potassium

This article is protected by copyright. All rights reserved. 
thiocyanate $(0-500 \mathrm{mg} / \mathrm{l})$ (based on The Institute of Gas Engineers analytical method for thiocyanate) ${ }^{42}$.

\section{Colour}

Samples were filtered through a $0.45 \mu \mathrm{m}$ filter and the residual colour was then analysed using a Jenway 6300 spectrophotometer (Staffordshire, UK) at a wavelength of $470 \mathrm{~nm}^{43}$.

\section{Suspended solids (SS)}

Suspended solids were analysed according to standard methods ${ }^{44}$. A $100 \mathrm{ml}$ sample was filtered $(1.25 \mu \mathrm{m}$ filter $)$ and dried at $105 \pm 5^{\circ} \mathrm{C}$ for 1 hour. Filter papers were then weighed and dried until a constant weight was achieved.

\section{PAHs}

Samples were collected and stored at $2-8^{\circ} \mathrm{C}$. Analysis was based on ISO 11338-2 ${ }^{45}$. Samples were filtered (Whatman GF/C $70 \mathrm{~mm}$ diameter) to separate the particulate matter from the liquid phase. The particulate matter was dried for $12 \mathrm{~h}$ in a fume cupboard and subsequently extracted by accelerated solvent extraction with dichloromethane at 2000 psi and $150^{\circ} \mathrm{C}$ using a Dionex ASE 200 (Runcorn, UK). Filters were placed into the cells where they were filled with dichloromethane. The solvent containing the organics was then flushed out under a nitrogen stream. The dichloromethane extract was then concentrated, solvent exchanged with methanol, added to the liquid phase and then extracted using an AutoTrace solid phase extractor (Caliper Life Sciences). The PAH SPE extraction cartridges (750 mg/3 ml) were conditioned with methanol and water. The samples were loaded and PAHs were retained on the cartridge which was rinsed with methanol and water $(20 / 80 \mathrm{v} / \mathrm{v})$ and dried under a stream of nitrogen. The PAH fraction was then eluted using tetrahydrofuran and hexane. The extract was then solvent exchanged with hexane and analysed using GC-MS

This article is protected by copyright. All rights reserved. 
(Agilent 6890 Gas Chromatograph coupled to a Agilent 5973 MSD Mass Spectrometer). A capillary column (Agilent DB-5MS) was used with a constant flow rate operating under temperatures between $50^{\circ} \mathrm{C}$ and $310^{\circ} \mathrm{C}$ at specified rates and intervals over a 55 minute timescale. The $\Sigma 6$ PAHs quantified were fluoranthene, benzo[b+j]fluoranthene, benzo[k]fluoranthene, benzo[a]pyrene, indeno[1,2,3-cd]pyrene and benzo[g,h,i]perylene.

Trace metals

Samples were analysed for total metals, aluminium (Al), vanadium (V), chromium (Cr), manganese $(\mathrm{Mn})$, iron $(\mathrm{Fe})$, cobalt $(\mathrm{Co})$, nickel $(\mathrm{Ni})$, copper $(\mathrm{Cu})$, zinc $(\mathrm{Zn})$, arsenic $(\mathrm{As})$, cadmium $(\mathrm{Cd})$ and lead $(\mathrm{Pb})$ based on ISO method $17294-1^{46}$. For the analysis of total metal concentrations, $3 \mathrm{ml}$ of nitric acid were added to $27 \mathrm{ml}$ of sample and placed on a hotplate for $2 \mathrm{~h}$ at $90^{\circ} \mathrm{C}$. Each sample was then digested using a CEM Microwave Assisted Reaction System (MARS) using XP-1500 Plus High-Pressure Digestion vessels. Samples were then analysed using an Agilent 7500cx ICP/MS (Stockport, UK) with an Octopole Reaction System in order to overcome interferences (Agilent Technologies).

\section{Statistical analysis}

Due to the high degree of natural variation in $\mathrm{PAH}$ concentrations measured in the wastewater feeding the pilot-plant both PAH and trace metal data was analysed statistically using an f-test, to ensure that the data fitted within a normal range of variance. PAH data was analysed using a paired T-Test at a 90\% confidence level. Trace metal data was analysed using a paired T-Test with $95 \%$ confidence level.

\section{RESULTS AND DISCUSSION}

\section{Wastewater characterisation}

This article is protected by copyright. All rights reserved. 
On average the full-scale coke making wastewater contained $221 \mathrm{mg} / \mathrm{L}$ of total phenol and $195 \mathrm{mg} / \mathrm{L}$ of thiocyanate $\left(\mathrm{SCN}^{-}\right)$(Table II). Trace metal concentrations ranged from 0.13 $\mu \mathrm{g} / \mathrm{L} \mathrm{Cd}$ to $3612 \mu \mathrm{g} / \mathrm{L} \mathrm{Fe}$. Therefore, Fe constituted the majority of the total trace metals measured at $4216 \mu \mathrm{g} / \mathrm{L}$ (Table II). The $\Sigma 6 \mathrm{PAHs}$ presented typical total concentrations of 179 $\mu \mathrm{g} / \mathrm{L}$. Individual PAHs varied from $13.6 \mu \mathrm{g} / \mathrm{L}$ (benzo[g,h,i]perylene) to $64.4 \mu \mathrm{g} / \mathrm{L}$ (fluoranthene). The new emission limit for the $\Sigma 6 \mathrm{PAHs}$ to achieve following treatment is 50 $\mu \mathrm{g} / \mathrm{L}$, hence effective treatment of PAHs in the treatment facility is crucial to achieve the required limit ${ }^{13}$.

Table II: Typical characteristics of coke making wastewater before and after treatment in the ASP pilot- plant during control operational conditions (without PAC treatment) and their associated treatment efficiencies.

\section{Comparison of treatment efficiencies of the pilot-plant and full-scale treatment works during the control period (without PAC dosing)}

During the control period the ASP achieved total phenol and $\mathrm{SCN}^{-}$removal efficiencies comparable to the full-scale treatment works. Effluent $\mathrm{SCN}^{-}$averaged at $0.7 \mathrm{mg} / \mathrm{L}$ leading to an average removal efficiency for $\mathrm{SCN}^{-}$was $99 \%$. Removal efficiencies remained stable despite fluctuations in inlet feed concentrations allowing compliance with the $4 \mathrm{mg} / \mathrm{L}$ emission limit (Figure II). Total phenol removal reached 97\%, which was in the same order of magnitude as the full-scale treatment removal efficiency of $99 \%$ (Figure II). Such results confirmed that the pilot-plant was operating effectively. Removal efficiencies of total phenol and $\mathrm{SCN}^{-}$were maintained during the addition of PAC demonstrating that PAC did not impact the removal of the biodegradable pollutants $\mathrm{SCN}^{-}$and total phenol (Figure II).

This article is protected by copyright. All rights reserved. 
Similarly, Chao et al. ${ }^{26}$ reported removal of total phenol to $<1 \mathrm{mg} / \mathrm{L}$ and therefore observed no improvement in total phenol removal at dose rates of $200-1000 \mathrm{mg} / \mathrm{L}$. Although both $\mathrm{SCN}^{-}$and total phenol were efficiently degraded by the well adapted biomass under control conditions it was equally important that no negative impacts were observed as emissions of both $\mathrm{SCN}^{-}$and total phenol are regulated under the IED.

Figure II: a - Removal efficiency of total phenol and SCN during the control ASP and ASP dosed with $400 \mathrm{mg} / \mathrm{L} \mathrm{PAC.} \bullet S C N^{-}$without PAC, $\circ S C N^{-}$with $400 \mathrm{mg} / \mathrm{L} \mathrm{PAC}$, a Total phenol without PAC, $\square$ total phenol with $400 \mathrm{mg} / \mathrm{L}$ PAC. b - Suspended solid concentrations in outlet during the control ASP and ASP dosed with $400 \mathrm{mg} / \mathrm{L}$ PAC.

Suspended solids without PAC, $\square$ suspended solids with $400 \mathrm{mg} / \mathrm{L}$ PAC. c-Colour removal efficiency during the control ASP and ASP dosed with $400 \mathrm{mg} / \mathrm{L}$ PAC. MColour removal efficiency without PAC, $\square$ colour removal efficiency with $400 \mathrm{mg} / \mathrm{L} \mathrm{PAC}$.

\section{Impact of PAC addition on suspended solids (SS) and colour removal}

The SS removal showed a small increase from $20 \mathrm{mg} / \mathrm{L}$ to $24 \mathrm{mg} / \mathrm{L}$, before and after PAC dosing, respectively. Despite this, the standard deviation of the SS measurement after PAC dosing (SD) decreased from 11 to $7 \mathrm{mg} / \mathrm{L}$, suggesting a small improvement on sludge settling characteristics. The use of AC in ASP processes has been reported to promote rapid settling and enhance sludge dewatering, which are added benefits of the AC dosing ${ }^{32}$. Addition of PAC resulted in a 5\% improvement in colour removal, which was lower than other values previously reported. The use of PAC in the treatment of steel mill coke effluent at a dose of $300 \mathrm{mg} / \mathrm{L}$ resulted in a $50 \%$ removal of colour ${ }^{26}$. Zhang et al. ${ }^{40}$ reported a $90 \%$ colour

This article is protected by copyright. All rights reserved. 
removal when treating coking wastewater with activated coke, however, this was at a much larger dosing rate of $200 \mathrm{~g} / \mathrm{L}$ and under batch rather than continuous operational conditions.

\section{Impact of PAC addition on trace metals removal}

Addition of PAC to the ASP led to variable removals of trace metals (Table III). Cadmium, a Priority Hazardous Substance (PHS), showed improved removal with average efficiency, increasing from $45.4 \%$ to $57.8 \%$, after PAC dosing. Cadmium removal was also more stable with the removal efficiency standard deviation decreasing from $16 \%$ to $11 \%$. Trace metal removal has been strongly associated with the $\mathrm{pH}$ of a solution due its role in influencing the ion charge and associated characteristics ${ }^{48}$. The $\mathrm{pH}$ in this study was not at the optimum for Cd removal averaging at 6.8. During batch tests with GAC Leyva-Ramos et al. ${ }^{49}$ reported a twelve fold increase in adsorption and associated removal of $\mathrm{Cd}(\mathrm{II})$ with a $\mathrm{pH}$ change of 3 to 8.

Table III: Average treatment efficiencies for the removal of trace metals, in the continuous activated sludge pilot-plant with and without $P A C$, showing a significant increase in the removal of Ni using T-test statistical analysis.

Figure III: Removal of nickel $\bullet$ Inlet no AC, ○ inlet $400 \mathrm{mg} / \mathrm{L} A C$. 口 Outlet no AC, $\square$ outlet $400 \mathrm{mg} / \mathrm{L}$ AC, showing increased stability of outlet Ni concentrations.

The largest improvement in trace metals removal was observed for Ni. Addition of PAC to the ASP process led to a significant improvement in $\mathrm{Ni}$ with an increase in average removal

This article is protected by copyright. All rights reserved. 
efficiency of $22.6 \%$. As with $\mathrm{Cd}$, the average removal efficiency became more stable with the standard deviation being observed to fall from $12.3 \%$ to $7.7 \%$ (Table III). Through batch tests with AC, Karnib et al. ${ }^{37}$ found that Ni showed the greatest removal efficiency in comparison to $\mathrm{Pb}, \mathrm{Zn}$ and $\mathrm{Cd}$ for each of the tested metal concentrations of $30-200 \mu \mathrm{g} / \mathrm{L}$. PAC was also identified as the best absorbent for $\mathrm{Ni}$ in batch tests due to its higher surface area $\left(710 \mathrm{~m}^{2} / \mathrm{g}\right)$ compared to other tested AC products which were characterised by lower surface areas (420$\left.485 \mathrm{~m}^{2} / \mathrm{g}\right)^{50}$. The PAC selected in this investigation had a lower surface area than the PAC products tested by Rao et al. ${ }^{50}$, however, it managed to achieve higher removal rates at lower dose rates. Rao et al. ${ }^{50}$ also reported an optimum $\mathrm{pH}$ of 8 for maximum $\mathrm{Ni}$ removal (56\% with $1000 \mathrm{mg} / \mathrm{L} \mathrm{PAC)}$. As stated earlier the studied ASP process, with a $\mathrm{pH}$ of 6.8, was operating below the reported optimum of 8 but despite this a dose rate of $400 \mathrm{mg} / \mathrm{L}$ was capable of a removal efficiency of $69.5 \%$. Powdered activated carbon addition resulted in a 20.5\% improvement in $\mathrm{Cr}$ removal. As in the case of $\mathrm{Ni}$ and $\mathrm{Cd}$, the observed removal efficiency standard deviation decreased from $40.7 \%$ to $14.0 \%$, after PAC dosing.

The average removal efficiency of $\mathrm{Zn}$ increased by just $2 \%$ leading to no significant difference. $\mathrm{Zn}$ removal has been shown to be dependent on individual treatment process conditions ( $\mathrm{pH}$ and temperature) and the type of $\mathrm{AC}{ }^{38}$. For some $\mathrm{AC}$ products temperature has little impact on adsorption whilst for others temperature increases also increased removal ${ }^{38}$. At $27^{\circ} \mathrm{C}$, the temperature in the studied ASP process, should have encouraged $\mathrm{Zn}$ removal, however, only small improvements were seen suggesting that the PAC selected in the current application may lack the acidic adsorption sites necessary for $\mathrm{Zn}$ adsorption.

This article is protected by copyright. All rights reserved. 
Although improvements were seen in the removal of some trace metals after PAC dosing, this was not observed for all metals investigated. Trace metal removals for $\mathrm{Al}, \mathrm{Mn}, \mathrm{Fe}, \mathrm{Co}$, $\mathrm{Cu}$, As and $\mathrm{Pb}$ were shown to decline (Table III). The presence of a mixture of trace metals in the wastewater may be responsible for some removal efficiencies being lower than those reported in literature. Many investigations consider the ability of AC to improve the removal of a single trace metal. When numerous trace metals are present, their ability to compete for available active sites impacts the observed removal efficiencies. Petrov et al. ${ }^{51}$ reported that the presence of $\mathrm{Cu}^{2+}, \mathrm{Pb}^{2+}, \mathrm{Zn}^{2+}$ and $\mathrm{Cd}^{2+}$ in equal quantities resulted in decreased adsorptions of each. This was due to the preferential adsorption of $\mathrm{Cd}^{2+}$ over the other metal ions $\left(\mathrm{Cd}^{2+}>\mathrm{Zn}^{2+}>\mathrm{Pb}^{2+}>\mathrm{Cu}^{2+}\right)$. Netzer and Hughes ${ }^{52}$ reported the impact of different contact time requirements of different metals, with those requiring less contact time demonstrating higher removals. Lead removal efficiencies, for example, decreased in the presence of other metals such as $\mathrm{Cu}$ and $\mathrm{Co}$. Low removal efficiencies of As in control conditions (12.6\%) and the further decline in efficiency when PAC was dosed $(0.5 \%)$ may be the result of such factors.

\section{Impact of PAC addition on PAHs removal}

$\Sigma 6 \mathrm{PAHs}$ entered the pilot-plant at $213 \pm 71 \mu \mathrm{g} / \mathrm{L}$ (Figure IV). Improvements in removal efficiencies were significant for fluoranthene, benzo[a]pyrene, indeno[1,2,3-cd]pyrene and benzo[g,h,i]perylene resulting in a significant improvement in the removal of the average

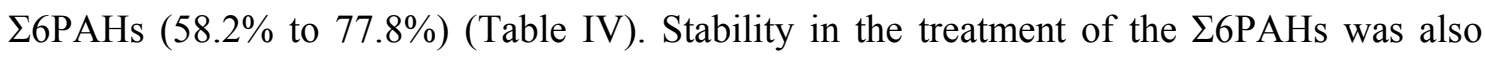
improved with a reduction of ca. 50\% in the standard deviation (Table IV). Overall the concentration of $\Sigma 6 \mathrm{PAHs}$ fell from an average of $54 \pm 21 \mu \mathrm{g} / \mathrm{L}$ under control conditions to 34 $\pm 11 \mu \mathrm{g} / \mathrm{L}$ after combined ASP and PAC addition (Table IV). Outlet concentrations were

This article is protected by copyright. All rights reserved. 
therefore in compliance with the new emission limit of $<50 \mu \mathrm{g} / \mathrm{L} \Sigma 6 \mathrm{PAHs}{ }^{13}$, demonstrating the benefit of adding PAC to ASP.

Figure IV: Removal of $\Sigma 6 \mathrm{PAHs}$. Inlet no AC, ○ inlet $400 \mathrm{mg} / \mathrm{L} \mathrm{AC}$. $\square$ Outlet no $A C$, $\square$ outlet $400 \mathrm{mg} / \mathrm{L} A C$.

Table IV: Average removal efficiency for $P A H s$ with and without $A C$ dosing in the continuous activated sludge pilot plant. Improvements in removal efficiency were significant and standard deviations were reduced by $50 \%$.

High molecular weight PAHs are known for increased persistence in the environment being characterised by high n-Octanol/water partition coefficients $\left(\log \mathrm{K}_{\mathrm{ow}}\right)^{35,53}$. Of the PAHs investigated $\log \mathrm{K}_{\mathrm{ow}}$ values range from 5.12 - 7.66 demonstrating their lipophilic nature and the likelihood of the PAHs to adsorb ${ }^{54,55}$. As AC contains macro as well as micro-pores it is particularly suitable for the sorption of PAHs including those of high molecular weights ${ }^{34}$. If the $\mathrm{PAH}$ mixture contains varying sizes there will therefore be an increased removal efficiency for smaller PAH molecules, especially in PAC, due to a higher number of micropores which are suitable for their sorption. The AC product used in this investigation was in powdered form. Consequently, micropores would outnumber macropores which could result in lower removal efficiencies of high molecular weight PAHs ${ }^{56}$. Both indeno[1,2,3cd]pyrene and benzo[g,h,i]perylene have a high molecular weight of $276 \mathrm{~g} / \mathrm{mol}$ and therefore improved removal of these more resistant PAHs is of notable importance. Despite PAC being characterised by fewer macropores improved removal efficiencies were seen for both

This article is protected by copyright. All rights reserved. 
indeno[1,2,3-cd]pyrene and benzo[g,h,i]perylene (28\% and 30\% respectively). Research into the effect of multiple PAH compounds occurring simultaneously suggests that the adsorption of PAHs will be influenced by the molecular weight of the compound ${ }^{56}$. This is a limiting factor in the current investigation.

Removal of PAHs was associated with adsorption due to their lipophilic nature and associated poor biodegradability ${ }^{15}$. Furthermore, biofilm formation would be limited as a result of the high levels of aeration applied in aeration cell and resulting shear ${ }^{57}$. Additionally, any further benefit of PAC in relation to biofilm formation would be limited as a result of the high SRT of 38 days present under normal operational conditions and a longterm adaptation period required for biofilm formation which was not accounted for in this investigation ${ }^{19}$. Longer-term investigations are required to investigate whether biofilm formation would result in biological degradation rather than adsorption alone.

\section{Economic feasibility of PAC addition to the ASP process}

In order to assess the economic feasibility of PAC addition to the ASP, for the removal of PAHs and trace metals from coke making wastewater, the capital expenditure (CAPEX) and operational expenditure (OPEX) were calculated (Table V). Costs were calculated for a fullscale ASP, following the configuration of the tested pilot-plant, based on an assumed plant with a capacity of $2000 \mathrm{~m}^{3} /$ day. A dose rate of $400 \mathrm{mg} / \mathrm{L}$ was selected due to the aforementioned comparison with the previous application by Chao et al. ${ }^{26}$, however, the selected dose rate has an important impact on observed removal efficiencies. Lü et al. ${ }^{58}$ reported that adsorption of phenol on lignite increased up to $500 \mathrm{mg} / \mathrm{L}$ and then remained stable. Similarly, Amuda et al. ${ }^{21}$ showed that $\mathrm{Zn}$ adsorption increased up until the point at which the adsorption peak is reached which was impacted by both the adsorbent type (as a

This article is protected by copyright. All rights reserved. 
result of the specific surface area) and the adsorbent dose. The economic costs are therefore specific to a dose rate of $400 \mathrm{mg} / \mathrm{L}$ and would therefore change in response to required dose rate optimisation.

The CAPEX costs consisted of the initial manual PAC dose required to reach a concentration of $400 \mathrm{mg} / \mathrm{L}$ in the aeration cell. Hence, an initial $800 \mathrm{~kg}$ of PAC would be required representing a cost of $£ 760$ ( $£ 0.38$ per $\mathrm{m}^{3}$ wastewater). The OPEX costs consisted of the cost of PAC addition required to maintain a dose rate of $400 \mathrm{mg} / \mathrm{L}$. The amount of PAC lost via sludge wasting was therefore calculated. Suspended solids in the wasted sludge were 15,000 $\mathrm{mg} / \mathrm{L}$ with PAC accounting for $4 \%$ of the suspended solids. Assuming sludge was wasted at 5 $\mathrm{L} / \mathrm{m}^{3}$ of treated effluent, this would lead to a total suspended solids loss of $54,750 \mathrm{~kg} / \mathrm{yr}$ resulting in an annual loss of PAC of $2190 \mathrm{~kg} / \mathrm{yr}$, costing $£ 2081 / \mathrm{yr}$. Therefore, loss of PAC through suspended solids represents a cost of $£ 2.85$ per $1000 \mathrm{~m}^{3}$ of wastewater or less than $£ 0.01$ per $\mathrm{m}^{3}$ of wastewater. The excess sludge was returned to the full-scale coke making process, hence no costs of sludge disposal were predicted in this study.

\section{Table V: CAPEX and OPEX cost analysis of PAC dosing to full-scale ASP.}

The costs associated with the addition of PAC were then compared to the CAPEX and OPEX costs of alternative techniques available to improve removals of PAHs and trace metals in wastewater. Tiravanti et al. ${ }^{59}$ demonstrated the economic feasibility of ion exchange processes for $\mathrm{Cd}$ removal from tannery wastewater. Costs were estimated at ca. $£ 1.85$ per $\mathrm{m}^{3}$ of wastewater. This represented an improvement on the conventional physiochemical treatment method which cost ca. $£ 2.43$ per $\mathrm{m}^{3}$. Heavy metal removal can be achieved through

This article is protected by copyright. All rights reserved. 
the application of coagulation followed by sand filtration. Høibye et al. ${ }^{60}$ considered the economic viability of sand filtration taking a holistic approach to the cost calculation. This considered both the potential and prevented environmental costs of the application, leading to an expense of $£ 0.04$ per $\mathrm{m}^{3}$. Costs were also compared to the treatment of textile wastewater, which is considered a complex effluent ${ }^{61}$ as is the case with coke making wastewater. Typical treatment often uses a combination of biological, physical and chemical treatment methods, with costs being reported as $£ 0.28$ per $\mathrm{m}^{3}$. When combined with electrochemical treatment, operating costs were reduced to $£ 0.21$ per $\mathrm{m}^{3}{ }^{61}$. Additionally, the cost of PAC addition was compared to the use of membranes and ozone (Table VI). Reports into the economics of these techniques focus on the treatment of domestic wastewater. Pollutants requiring treatment in domestic wastewater are typically $10-100$ times lower than concentrations observed in coke making wastewater whilst the consent limits are typically higher than those required by the IED for coke making wastewater and therefore this requires consideration when comparing treatment costs. Furthermore, reported costs can vary significantly for the use of membranes due to the varying pre-treatment costs which can be extensive ${ }^{62}$.

Table VI: Economic feasibility of PAC addition to the ASP in comparison to other treatment methods.

PAC addition therefore offers an economically favourable option to achieve improvements in pollutant removal. Capital expenditure is minimal when PAC is dosed directly into the ASP process as it removes the requirement for plant modifications such as the installation of adsorption columns and pumps. The economic advantage of direct addition to an ASP was

This article is protected by copyright. All rights reserved. 
also reported by Flynn and Stadnik ${ }^{63}$ who reported savings of ca. $£ 4.5$ million in CAPEX costs and a £3.2 million saving in OPEX costs compared to GAC columns. Operational costs are also cheaper than other removal strategies such as sand filtration and ion exchange processes. Treatment processes used for domestic wastewater such as ozonation and membrane filtration have high CAPEX and OPEX costs. As industrial wastewaters, such as coke making wastewater, are characterised by higher pollutant concentrations the use of ozonation and membranes is associated with further economic costs and therefore PAC offers an economically viable treatment method for coke making wastewaters.

\section{CONCLUSION}

The ASP pilot-plant performed similarly to the full-scale treatment works regarding total phenol and $\mathrm{SCN}^{-}$with removal efficiencies at $99 \%$, and $97 \%$, respectively, demonstrating effective treatment. Powdered activated carbon dosing to ASP increased the removal efficiency of a range of trace metals and PAHs associated with coke making wastewater. In the case of $\mathrm{Ni}$ the removal increased by $22.6 \%$ whilst the $\Sigma 6 \mathrm{PAH}$ removal efficiency increased by ca. $20 \%$. Overall the $\Sigma 6 \mathrm{PAHs}$ concentration was reduced to $34 \mu \mathrm{g} / \mathrm{L}$, allowing compliance with the new emission limit of $<50 \mu \mathrm{g} / \mathrm{L} \Sigma 6 \mathrm{PAHs}$ at relatively low capital and operational costs, which may assist in reaching tighter effluent emission limits set for the steel industry. Other wastewaters containing PAH and trace metal, from industries such as agrochemical, pharmaceutical, petrochemical, coal gasification, coke processing, insecticide, hydrocarbon and produced wastewaters amongst others, may benefit from PAC addition in a future of increasingly stringent emission limits. Overall, PAC addition was associated with a CAPEX cost of $£ 0.38$ per $\mathrm{m}^{3}$ and an OPEX cost of $<£ 0.01$ per $\mathrm{m}^{3}$, offering an economically viable method to remove pollutants from coke making wastewater.

This article is protected by copyright. All rights reserved. 


\section{ACKNOWLEDGEMENTS}

This work was supported by Tata Steel and the Natural Environment Research Council [grant number NE/K007424/1].

This article is protected by copyright. All rights reserved. 


\section{References}

1. Kim, Y. M., Park, D., Jeon, C. O., Lee, D. S. \& Park, J. M. Effect of HRT on the biological pre-denitrification process for the simultaneous removal of toxic pollutants from cokes wastewater. Bioresour. Technol. 99, 8824-32 (2008).

2. Zhu, X., Tian, J. \& Chen, L. Phenol degradation by isolated bacterial strains: Kinetics study and application in coking wastewater treatment. J. Chem. Technol. Biotechnol. 87, 123-129 (2012).

3. Marañón, E. et al. Treatment of coke wastewater in a sequential batch reactor (SBR) at pilot plant scale. Bioresour. Technol. 99, 4192-8 (2008).

4. Wei, X., Zhang, Z., Fan, Q., Yuan, X. \& Guo, D. The effect of treatment stages on the coking wastewater hazardous compounds and their toxicity. J. Hazard. Mater. 239240, 135-41 (2012).

5. Vázquez, I., Rodríguez, J., Marañón, E., Castrillón, L. \& Fernández, Y. Simultaneous removal of phenol, ammonium and thiocyanate from coke wastewater by aerobic biodegradation. J. Hazard. Mater. 137, 1773-80 (2006).

6. Pal, P. \& Kumar, R. Treatment of Coke Wastewater: A Critical Review for Developing Sustainable Management Strategies. Sep. Purif. Rev. 43, 89-123 (2014).

7. Zhang, W. et al. Identification and removal of polycyclic aromatic hydrocarbons in wastewater treatment processes from coke production plants. Environ. Sci. Pollut. Res. Int. 20, 6418-32 (2013).

8. Chen, J., Aries, E., Collins, P., Anderson, D. R. \& Hodges, J. S. Characterisation of Priority Substances in Effluents from an Integrated Steelworks in the United Kingdom. Water Environ. Res. 87, 132-144 (2015).

9. Ganczarczyk, J. J. Second-Stage Activated Sludge Treatment of Coke-Plant Effluents. Water Res. 13, 337-342 (1983).

10. Gould, F. J. Biological effluent treatment using pure oxygen. The Coke Oven Managers' Yearbook (1986).

11. Staib, C. \& Lant, P. Thiocyanate degradation during activated sludge treatment of coke-ovens wastewater. Biochem. Eng. J. 34, 122-130 (2007).

12. Bai, Y., Sun, Q., Zhao, C., Wen, D. \& Tang, X. Bioaugmentation treatment for coking wastewater containing pyridine and quinoline in a sequencing batch reactor. Appl. Microbiol. Biotechnol. 87, 1943-1951 (2010).

13. European Commission. Best Available Techniques (BAT) Reference Document for Iron and Steel Production. Industrial Emissions Directive 2010/75/EU BREF-IS, (2013).

14. Zhang, W. et al. The behaviors and fate of polycyclic aromatic hydrocarbons (PAHs) in a coking wastewater treatment plant. Chemosphere 88, 174-182 (2012).

15. Burmistrz, P. \& Burmistrz, M. Distribution of polycyclic aromatic hydrocarbons in coke plant wastewater. Water Sci. Technol. 68, 2414-20 (2013).

16. European Commission. Priority Substances and Certain Other Pollutants according to Annex II of Directive 2008/105/EC. (2014). Available at: http://ec.europa.eu/environment/water/water-framework/priority_substances.htm.

This article is protected by copyright. All rights reserved. 
(Accessed: 13th August 2014)

17. European Parliament. Directive 2000/60/EC of the European Parliament and of the Council of 23 October 2000 establishing a framework for Community action in the field of water policy. (2000). Available at: http://eurlex.europa.eu/LexUriServ/LexUriServ.do?uri=CELEX:32000L0060:EN:NOT. (Accessed: 25th November 2013)

18. Jianlong, W., Xiangchun, Q., Libo, W., Yi, Q. \& Hegemann, W. Bioaugmentation as a tool to enhance the removal of refractory compound in coke plant wastewater. Process Biochem. 38, 777-781 (2002).

19. Augulyte, L. et al. Multivariate analysis of a biologically activated carbon (BAC) system and its efficiency for removing PAHs and aliphatic hydrocarbons from wastewater polluted with petroleum products. J. Hazard. Mater. 170, 103-10 (2009).

20. Crisafully, R. et al. Removal of some polycyclic aromatic hydrocarbons from petrochemical wastewater using low-cost adsorbents of natural origin. Bioresour. Technol. 99, 4515-9 (2008).

21. Amuda, O. S., Giwa, A. A. \& Bello, I. A. Removal of heavy metal from industrial wastewater using modified activated coconut shell carbon. Biochem. Eng. J. 36, 174181 (2007).

22. Goel, J., Kadirvelu, K., Rajagopal, C. \& Kumar Garg, V. Removal of lead ( II ) by adsorption using treated granular activated carbon: Batch and column studies. $J$. Hazard. Mater. B125, 211-220 (2005).

23. Meidl, J. A. Responding to changing conditions: How powdered activated carbon systems can provide the operational flexibility necessary to treat contaminated groundwater and industrial wastes. Carbon N. Y. 35, 1207-1216 (1997).

24. De Walle, F. B., Chian, E. S. K. \& Small, E. M. Organic matter removal by PAC added to activated sludge. Water Pollut. Control Fed. 49, 593-99 (1977).

25. Kunz, R. G. \& Giannelli, J. F. Activated carbon adsorption of cyanide complexes and thiocyanate ion from petrochemical wastewaters. Carbon N. Y. 14, 157-161 (1976).

26. Chao, Y. M., Yeh, T. F. \& Shieh, W. K. PAC-Activated Sludge Treatment of a Steel Mill Coke-Plant Wastewater. Water Environ. Fed. 58, 333-338 (1986).

27. Bansode, R. R., Losso, J. N., Marshall, W. E., Rao, R. M. \& Portier, R. J. Pecan shellbased granular activated carbon for treatment of chemical oxygen demand (COD) in municipal wastewater. Bioresour. Technol. 94, 129-135 (2004).

28. Nicolet, L. \& Rott, U. Recirculation of powdered activated carbon for the adsorption of dyes in municipal wastewater treatment plants. Water Sci. Technol. 40, 191-198 (1999).

29. Hussain, S. et al. Orthophosphate removal from domestic wastewater using limestone and granular activated carbon. Desalination 271, 265-272 (2011).

30. Boehler, M. et al. Removal of micropollutants in municipal wastewater treatment plants by powder-activated carbon. Water Sci. Technol. 66, 2115-2121 (2012).

31. Joyce, R. S., Allen, J. B. \& Sukenik, V. A. Treatment of Municipal Wastewater by Packed Activated Carbon Beds. J. Water Pollut. Control Fed. 38, 813-823 (1966).

32. Çeçen, F. \& Aktaş, Ö. Activated Carbon for water and wastewater treatment: Integration of adsorption and biological treatment. (Wiley-VCH, 2011).

This article is protected by copyright. All rights reserved. 
33. Bornhardt, C., Drewes, J. E. \& Jekel, M. Removal of organic halogens (AOX) from municipal wastewater by powdered activated carbon (PAC) activated sludge (AS) treatment. Water Sci. Technol. 35, 147-153 (1997).

34. Valderrama, C., Gamisans, X., de las Heras, X., Farran, A. \& Cortina, J, L. Sorption kinetics of polycyclic aromatic hydrocarbons removal using granular activated carbon: Intraparticle diffusion coefficients. J. Hazard. Mater. 157, 386-396 (2008).

35. Abu-salah, K., Shelef, G., Levanon, D., Armon, R. \& Dosoretz, C. G. Microbial degradation of aromatic and polyaromatic toxic compounds adsorbed on powdered activated carbon. J. Biotechnol. 51, 265-272 (1996).

36. Budinova, T. et al. Biomass waste-derived activated carbon for the removal of arsenic and manganese ions from aqueous solutions. Appl. Surf. Sci. 255, 4650-4657 (2009).

37. Karnib, M., Kabbani, A., Holail, H. \& Olama, Z. Heavy Metals Removal Using Activated Carbon, Silica and Silica Activated Carbon Composite. Energy Procedia 50, 113-120 (2014).

38. Leyva Ramos, R., Bernal Jacome, L. A., Mendoza Barron, J., Fuentes Rubio, L. \& Guerrero Coronado, R. M. Adsorption of zinc (II) from an aqueous solution onto activated carbon. J. Hazard. Mater. B90 90, 27-38 (2002).

39. Kliaugaite, D., Jankunaite, D. \& Racys, V. Factors influencing treatment of petroleum polluted wastewater using biologically activated carbon. Environ. Eng. 569-575 (2008).

40. Zhang, M. H., Zhao, Q. L., Bai, X. \& Ye, Z. F. Adsorption of organic pollutants from coking wastewater by activated coke. Colloids Surfaces A Physicochem. Eng. Asp. 362, 140-146 (2010).

41. The Institution of Gas Engineers. Recommended analytical method for gas works and coke oven effluents: Booklet 1: Total phenols. (1967).

42. The Institution of Gas Engineers. Recommended analytical methods for gas works and coke oven effluents: Booklet 3: Thiocyanate. (1971).

43. Clesceri, L. S., Greenberg, A. E., Franson, M. A. H. \& Eaton, A. D. Standard methods for the examination of water and wastewater (20th edition): Method 2120: Colour spectrophotmetric method. (American Public Health Association, 1998).

44. Eaton, A. Standard methods for the examination of water and wastewater. (American Public Health Association, 2005).

45. ISO. British Standard EN ISO 11338-2: Stationary Source Emissions - Determination of Gas and Particle-Phase Polycyclic Aromatic Hydrocarbons- Part 2: Sample preparation, clean up and determination. (2003).

46. ISO. British Standard EN ISO 17294-1. Water Quality, Application of Inductively Coupled Plasma Mass Spectrometry (ICP-MS). General Guidelines. (2006).

47. Agilent Technologies. ICP-MS Inductively Coupled Plasma Mass Spectrometry: A Primer. Available at:

http://www.seaes.manchester.ac.uk/media/eps/schoolofearthatmosphericandenvironme ntalsciences/research/facilities/analyticalgeochemistry/equipment/icpmsprimer.pdf. (Accessed: 6th October 2014)

48. Mohan, D. \& Singh, K. P. Single- and multi-component adsorption of cadmium and zinc using activated carbon derived from bagasse - an agricultural waste. Water Res. 36, 2304-2318 (2002).

This article is protected by copyright. All rights reserved. 
49. Leyva-Ramos, R., Rangel-Mendez, J. R., Mendoza-Barron, J., Fuentes-Rubio, L. \& Guerrero-Coronado, R. M. Adsorption of cadmium (II) from aqueous solution onto activated carbon. Water Sci. Technol. 35, 205-211 (1997).

50. Rao, M., Parwate, A. V \& Bhole, A. G. Removal of Cr6+ and Ni2+ from aqueous solution using bagasse and fly ash. Waste Manag. 22, 821-830 (2002).

51. Petrov, N., Budinova, T. \& Khavesov, I. Adsorption of the ions of Zinc, Cadmium, Copper, and Lead on oxidized anthracite. Carbon N. Y. 30, 135-139 (1992).

52. Netzer, A. \& Hughes, D. E. Adsorption of Copper, Lead and Cobalt by activated carbon. Water Res. 18, 927-933 (1984).

53. Jeon, C. O. \& Madsen, E. L. In situ microbial metabolism of aromatic-hydrocarbon environmental pollutants. Curr. Opin. Biotechnol. 24, 474-81 (2013).

54. Popp, P., Bauer, C. \& Wennrich, L. Application of stir bar sorptive extraction in combination with column liquid chromatography for the determination of polycyclic aromatic hydrocarbons in water samples. Anal. Chim. Acta 436, 1-9 (2001).

55. de Maagd, P. G.-J., ten Hulscher, D. T. E. M., van den Heuvel, H., Opperhuizen, A. \& Sijm, D. T. H. M. Physicochemical properties of polycyclic aromatic hydrocarbons: Aqueous solubilities, n-octanol/water partition coefficients, and Henry's law constants. Environ. Toxicol. Chem. 17, 251-257 (1998).

56. Yuan, M., Tong, S., Zhao, S. \& Jia, C. Q. Adsorption of polycyclic aromatic hydrocarbons from water using petroleum coke-derived porous carbon. J. Hazard. Mater. 181, 1115-1120 (2010).

57. Mason, C. A., Ward, G., Abu-Salah, K., Keren, O. \& Dosoretz, C. G. Biodegradation of BTEX by bacteria on powdered activated carbon. Bioprocess Eng. 23, 331-336 (2000).

58. Lü, G. et al. The Adsorption of Phenol by Lignite Activated Carbon. Chinese J. Chem. Eng. 19, 380-385 (2011).

59. Tiravanti, G., Petruzzelli, D. \& Passino, R. Pretreatment of tannery wastewaters by an ion exhange process for Cr (III) removal and recovery. Water Sci. Technol. 36, 197207 (1997).

60. Høibye, L. et al. Sustainability assessment of advanced wastewater treatment technologies. Water Sci. Technol. 58, 963-8 (2008).

61. Lin, S. H. \& Peng, C. F. Continuous treatment of textile wastewater by combined coagulation, electrochemical oxidation and activated sludge. Water Res. 30, 587-592 (1996).

62. Black and Veatch. Evaluation \& Assessment of Removal Technology for Specific Organic Contaminants in NJ Drinking Water. (2008).

63. Flynn, B. P. \& Stadnik, G. Start-Up of a Powdered Activated Carbon- Activated Sludge Treatment System. J. Water Pollut. Control Fed. 51, 358-369 (1979).

64. RWE AG Pers.Comm. Activated lignite pricing. (2014).

This article is protected by copyright. All rights reserved. 
Table I: Priority Hazardous Substances (PHS), Priority Substances (PS) and Specific Pollutants (SP) associated with coke wastewaters.

\begin{tabular}{ll}
\hline \multirow{2}{*}{ Priority Hazardous Substances } & Anthracene \\
& Cadmium \\
& Benzo[a]pyrene \\
& Benzo[b]fluoranthene + Benzo[k]fluoranthene \\
& Fluoranthene \\
Priority Substances & Lead \\
& Naphthalene \\
& Nickel \\
& Iron \\
Specific Pollutants & Arsenic \\
& Chromium \\
& Zinc \\
\hline
\end{tabular}

This article is protected by copyright. All rights reserved. 
Table II: Typical characteristics of coke making wastewater before and after treatment in the ASP pilot plant during control operational conditions (without PAC treatment) and their associated treatment efficiencies.

\begin{tabular}{|c|c|c|c|c|c|}
\hline & Inlet & SD & Outlet & SD & $\begin{array}{c}\text { Treatment } \\
\text { efficiency }(\%)\end{array}$ \\
\hline Phenols (total) $(\mathrm{mg} / \mathrm{L})$ & 219 & 15 & 6.3 & 0.4 & 97 \\
\hline Thiocyanate (mg/L) & 195 & 24 & 0.6 & 0.2 & 100 \\
\hline Total trace metals $(\mu \mathrm{g} / \mathrm{L}) *$ & 4216 & 568 & 2878 & 220 & 35 \\
\hline Total of 6 PAHs $(\mu \mathrm{g} / \mathrm{L}) * *$ & 179 & 35 & 53.6 & 21 & 58 \\
\hline Suspended Solids (mg/L) & 23 & 8 & 20 & 3 & - \\
\hline Colour (Absorbance $470 \mathrm{n}$ ) & 0.32 & 0.03 & 0.31 & 0.01 & 2.04 \\
\hline \multicolumn{6}{|c|}{$\begin{array}{l}\text { * Sum of } \mathrm{Al}, \mathrm{Cr}, \mathrm{Mn}, \mathrm{Fe}, \mathrm{Co}, \mathrm{Ni}, \mathrm{Cu}, \mathrm{Zn}, \mathrm{As}, \mathrm{Cd} \text { and } \mathrm{Pb} \text {. } \\
\text { ** Sum of PAHs identified in BREF as associated with coke making- fluoranthene, } \\
\text { benzo[b]fluoranthene, benzo[k]fluoranthene, benzo[a]pyrene, indeno[1,2,3-cd]pyrene and } \\
\text { benzo[g,h,i]perylene. }\end{array}$} \\
\hline
\end{tabular}

This article is protected by copyright. All rights reserved. 
Table III: Average treatment efficiencies for the removal of trace metals, in the continuous activated sludge pilot plant with and without PAC, showing a significant increase in the removal of $\mathrm{Ni}$ using $\mathrm{T}$-test statistical analysis.

\begin{tabular}{lcccccc}
\hline & \multicolumn{2}{c}{ No activated lignite } & \multicolumn{2}{c}{$400 \mathrm{mg} / \mathrm{L}$ activated lignite } & \multicolumn{2}{c}{ T-test } \\
\hline & $\begin{array}{c}\text { Av. removal } \\
(\%)\end{array}$ & $\mathrm{SD}$ & $\begin{array}{c}\text { Av. removal } \\
(\%)\end{array}$ & SD & P-value & $\begin{array}{c}\text { Significant } \\
(95 \%) ?\end{array}$ \\
\hline & & & & & & \\
$\mathrm{Al}$ & 41.6 & 10.2 & 24.3 & 17.0 & 0.07 & $\mathrm{~N}$ \\
$\mathrm{Cr}$ & 16.7 & 40.7 & 37.2 & 14.0 & 0.33 & $\mathrm{~N}$ \\
$\mathrm{Mn}$ & 37.1 & 5.4 & 35.9 & 9.0 & 0.80 & $\mathrm{~N}$ \\
$\mathrm{Fe}$ & 29.8 & 6.0 & 24.7 & 5.9 & 0.16 & $\mathrm{~N}$ \\
$\mathrm{Co}$ & 18.4 & 1.6 & 12.5 & 8.8 & 0.10 & $\mathrm{~N}$ \\
$\mathrm{Ni}$ & 46.9 & 12.3 & 69.5 & 7.7 & 0.00 & $\mathrm{Y}$ \\
$\mathrm{Cu}$ & 65.5 & 6.2 & 61.5 & 9.2 & 0.42 & $\mathrm{~N}$ \\
$\mathrm{Zn}$ & 65.7 & 5.2 & 69.1 & 8.1 & 0.43 & $\mathrm{~N}$ \\
$\mathrm{As}$ & 12.6 & 6.3 & 0.5 & 17.9 & 0.10 & $\mathrm{~N}$ \\
$\mathrm{Cd}$ & 45.4 & 16.0 & 57.8 & 11.0 & 0.18 & $\mathrm{~N}$ \\
$\mathrm{~Pb}$ & 57.4 & 13.6 & 56.0 & 22.7 & 0.90 & $\mathrm{~N}$ \\
\hline
\end{tabular}

This article is protected by copyright. All rights reserved. 
Table IV: Average removal efficiency for PAHs with and without AC dosing in the continuous activated sludge pilot plant. Improvements in removal efficiency were significant and standard deviations were reduced by $50 \%$.

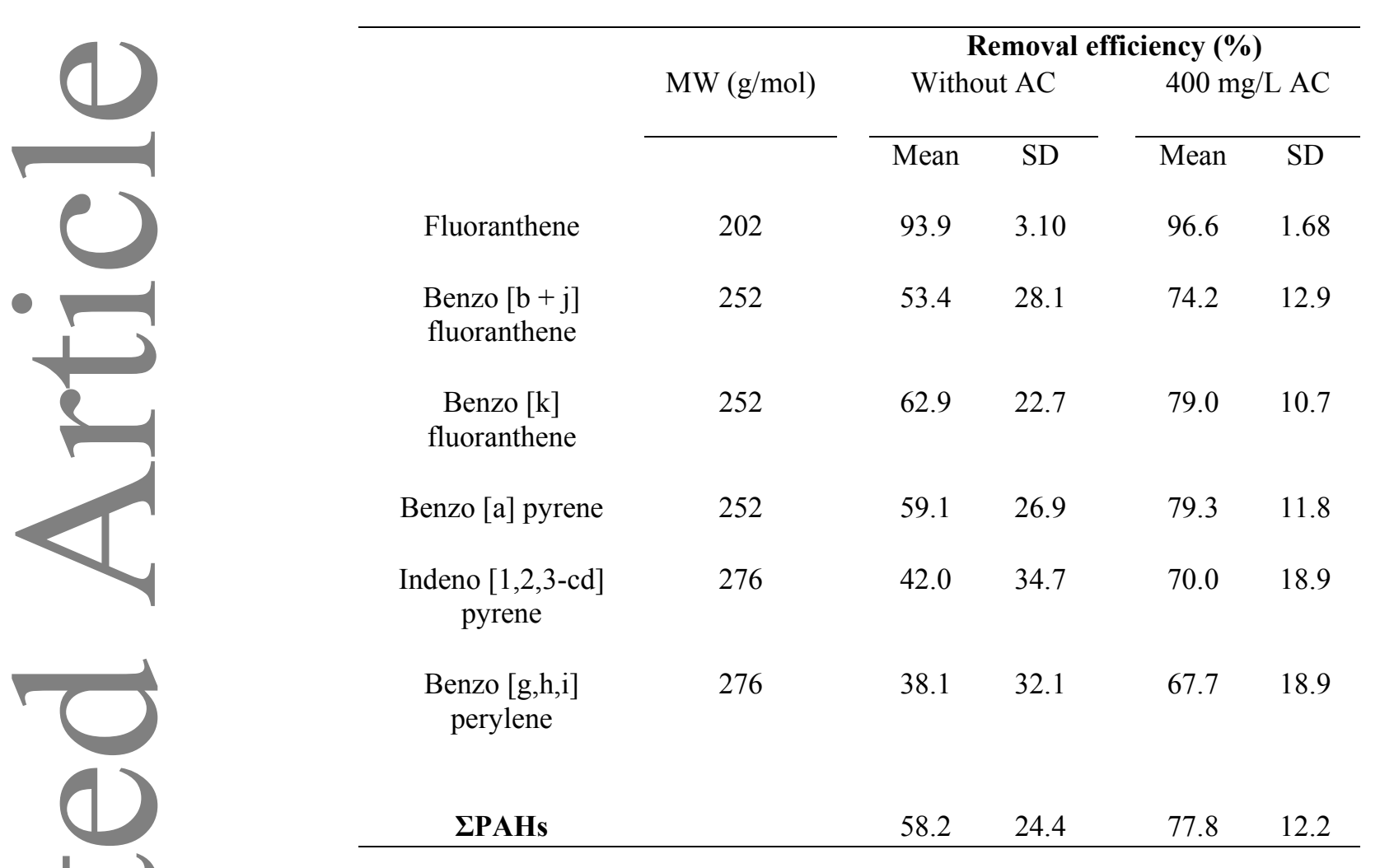

This article is protected by copyright. All rights reserved. 
Table V: CAPEX and OPEX cost analysis of PAC dosing to full-scale ASP.

\begin{tabular}{|c|c|}
\hline \multicolumn{2}{|l|}{ ASP plant configuration: } \\
\hline Plant capacity (m²day) & 2000 \\
\hline Suspended solids in wasted sludge $(\mathrm{mg} / \mathrm{L})$ & 15,000 \\
\hline Sludge wasted (L/day) & 10,000 \\
\hline $\mathrm{PAC}$ dose rate $(\mathrm{mg} / \mathrm{L})$ & 400 \\
\hline \multicolumn{2}{|l|}{ Costs and dosing associated with PAC addition: } \\
\hline Cost of PAC per $\mathrm{kg}(\mathfrak{f})^{64}$ & 0.95 \\
\hline Initial PAC dose required $(\mathrm{kg})$ & 800 \\
\hline Cost of PAC per $\mathrm{m}^{3}$ of wastewater $(\mathfrak{E})$ & 0.38 \\
\hline 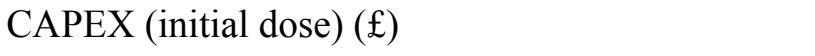 & 760 \\
\hline PAC lost via sludge wasting ( $\mathrm{kg} / \mathrm{yr})$ & 2190 \\
\hline Cost of PAC loss per $1000 \mathrm{~m}^{3}$ wastewater $(\mathfrak{E})$ & 2.85 \\
\hline OPEX cost (PAC required for maintenance) (£/yr) & 2081 \\
\hline
\end{tabular}

This article is protected by copyright. All rights reserved. 
Table VI: Economic feasibility of PAC addition to the ASP in comparison to other treatment methods.

\begin{tabular}{|c|c|c|c|c|}
\hline Technology & $\begin{array}{l}\text { Type of } \\
\text { wastewater }\end{array}$ & 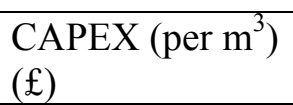 & $\begin{array}{l}\text { OPEX }\left(\text { per } \mathrm{m}^{3}\right) \\
(\mathfrak{f})\end{array}$ & Reference \\
\hline PAC & Coke making & 0.38 & $<0.01$ & This study \\
\hline Ozone & Mixed* & $583-972$ & 0.17 & \\
\hline Membrane & Domestic $* *$ & $810-1620$ & $0.22-1.33$ & 62 \\
\hline
\end{tabular}

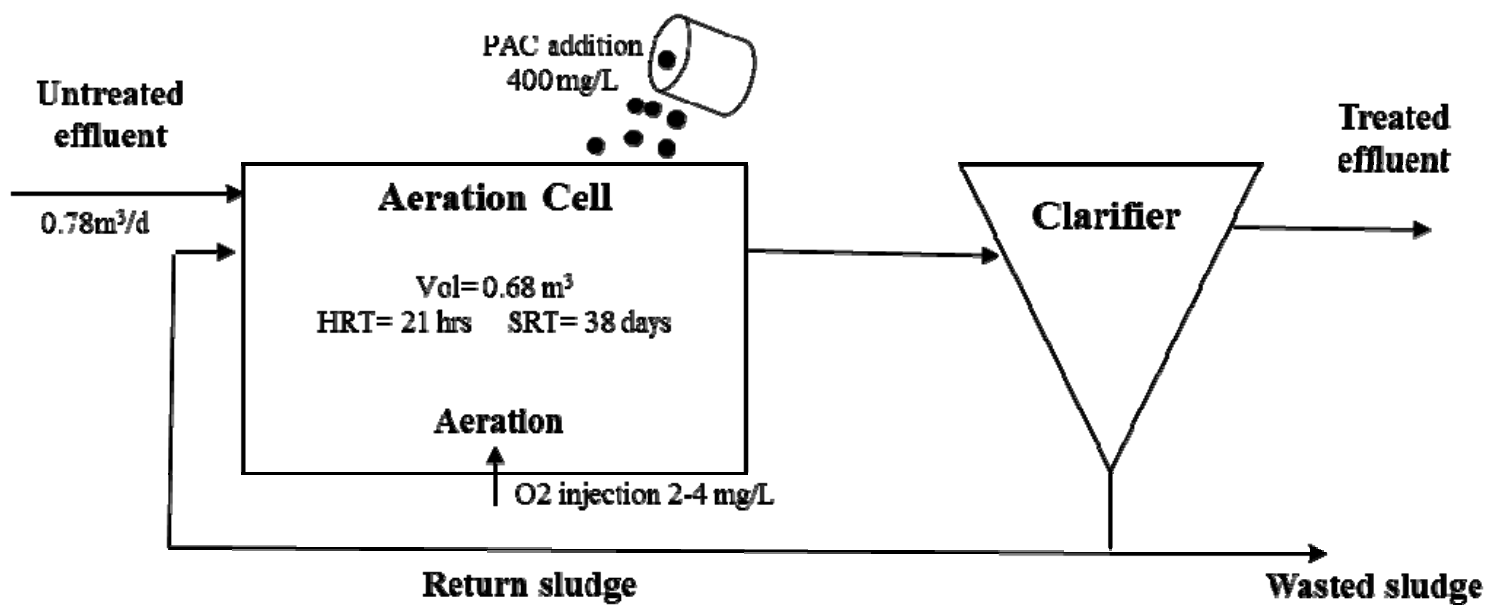

Figure I: Schematic representation of the activated sludge pilot-plant with PAC addition.

This article is protected by copyright. All rights reserved. 

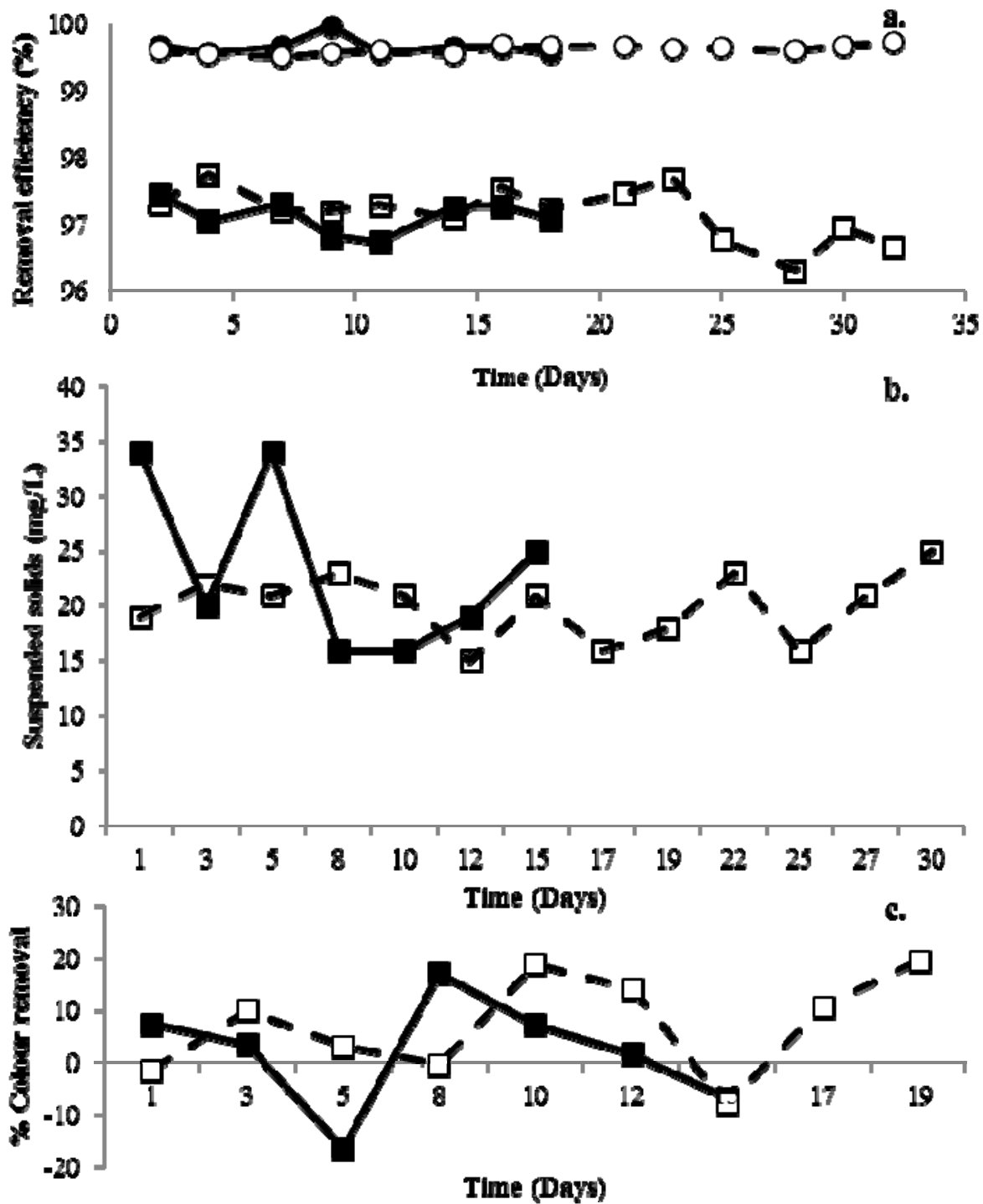

Figure II: a- Removal efficiency of phenol and $\mathrm{SCN}^{-}$during the control ASP and ASP dosed with $400 \mathrm{mg} / \mathrm{L}$ PAC. $\bullet \mathrm{SCN}^{-}$without PAC, ○ $\mathrm{SCN}^{-}$with $400 \mathrm{mg} / \mathrm{L} \mathrm{PAC}$, Phenol without PAC, $\square$ phenol with $400 \mathrm{mg} / \mathrm{L}$ PAC. b- Suspended solid concentrations in outlet during the control ASP and ASP dosed with $400 \mathrm{mg} / \mathrm{L} \mathrm{PAC}$. a Suspended solids without PAC, $\square$ suspended solids with $400 \mathrm{mg} / \mathrm{L}$ PAC. c- Colour removal efficiency during the control ASP and ASP dosed with $400 \mathrm{mg} / \mathrm{L}$ PAC. nColour removal efficiency without PAC, $\square$ colour removal efficiency with $400 \mathrm{mg} / \mathrm{L} \mathrm{PAC}$.

This article is protected by copyright. All rights reserved. 


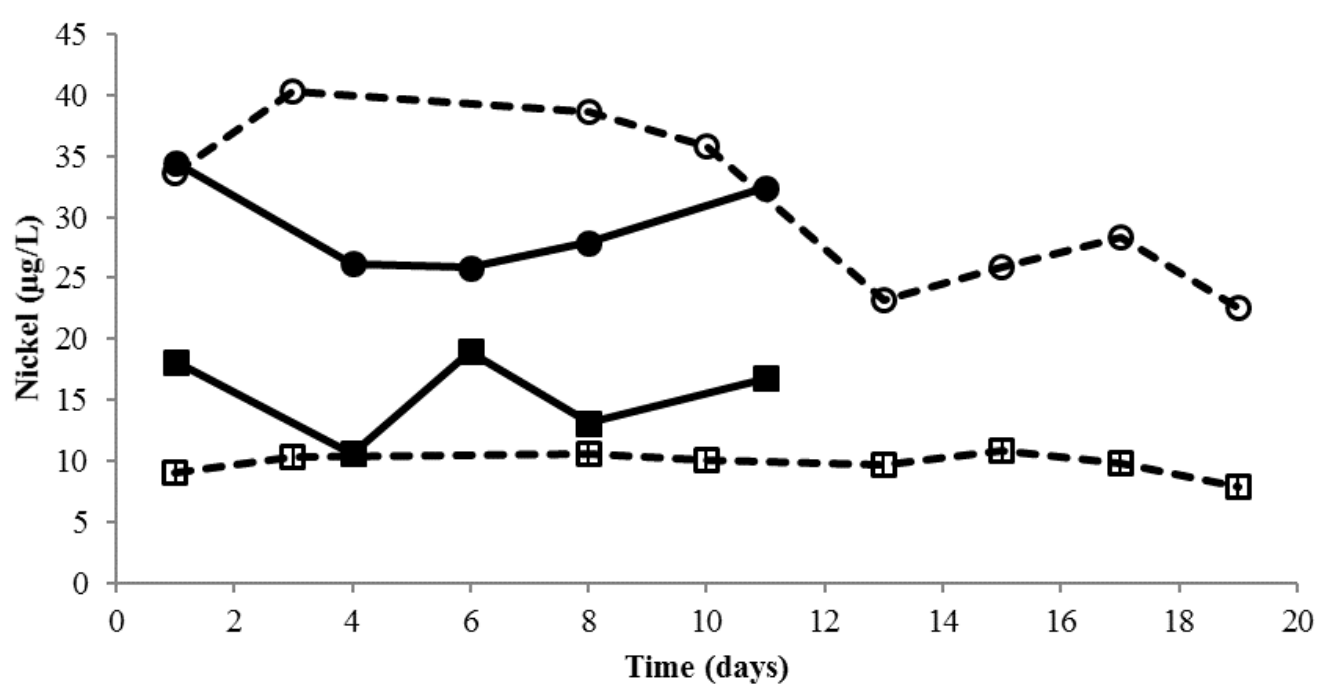

Figure III: Removal of nickel $\bullet$ Inlet no AC, $\odot$ inlet $400 \mathrm{mg} / \mathrm{L} \mathrm{AC}$. a Outlet no AC, $\square$ outlet $400 \mathrm{mg} / \mathrm{L}$ AC, showing increased stability of outlet Ni concentrations. Standard deviation of method typically 2.5 .

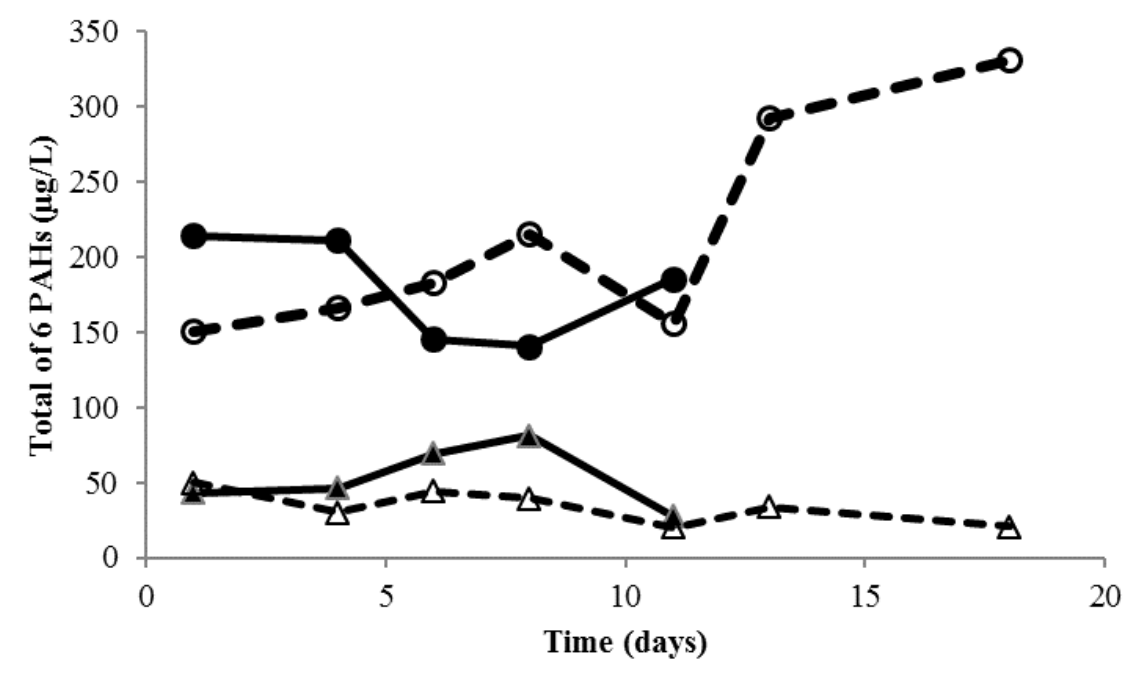

Figure IV: Removal of $\Sigma 6$ PAHs. • Inlet no AC, ○ inlet $400 \mathrm{mg} / \mathrm{L}$ AC. a Outlet no AC, $\square$ outlet $400 \mathrm{mg} / \mathrm{L}$ AC. Standard deviation of method typically equal to 0.15 .

This article is protected by copyright. All rights reserved. 